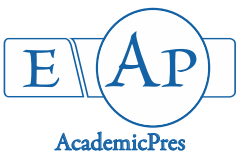

Akinlabi AA and Oladipo OT (2021)

Notulae Scientia Biologicae

Volume 13, Issue 2, Article number 10760

DOI: $10.15835 / \mathrm{nsb} 13210760$

Research Article

\title{
Venation studies of some species in the genus Ficus Linn. in Southwestern Nigeria
}

\author{
Adebisi A. AKINLABI*, Olaniran T. OLADIPO \\ Obafemi Awolowo University, Department of Botany, Ile - Ife, Osun State, Nigeria; akinlabiadebisi@yahoo.com (corresponding \\ author); niranoladipo.to@gmail.com
}

\begin{abstract}
The present study investigates the venation of ten species of the genus Ficus collected from Obafemi Awolowo University Ile-Ife (latitude $7^{\circ} 31^{\prime} 14.7612^{\prime \prime} \mathrm{N}$ and longitude $4^{\circ} 31^{\prime} 49.1340^{\prime \prime} \mathrm{E}$ ) and the NACGRAB, Ibadan, Nigeria (latitude $7^{\circ} 23^{\prime} 4^{\prime \prime} \mathrm{N}$ and longitude $3^{\circ} 50^{\prime} 31^{\prime \prime} \mathrm{E}$ ). The leaf venations of the species were carried out using standard methods. All photomicrographs of the features were taken with the aid of Amscope digital camera mounted on a celesterone binocular microscope. All data were subjected of analysis of variance using SAS software. The result revealed the Leaf venation pattern based on areole shape, length and width, veinlets ending and trichomes. The leaf venation patterns of the species show that they are significant in identifying and delimiting studied species within the genus with respect to qualitative and quantitative data. Species specific variation were recorded for the venation patterns as areole shape, length and width, veinlets ending and trichomes and these features are either genetically fixed or as a result of environmental extremes. Presence of cystolith cells, trichomes and no veinlets ending is diagnostic of Ficus mucuso. The study concluded that venation patterns are therefore significant in delimitation of species in the genus Ficus and these characters can be employed as additional information in the existing taxonomical keys of the genus.
\end{abstract}

Keywords: areole; cystolith cells; leaf; shape; venation

\section{Introduction}

The genus Ficus belongs to the family Moraceae and also amongst the largest genera of higher plants (Scott, 1996; Frodin, 2004). Ficus is one of the most diverse woody plant genera globally (Berg, 1989; Chaudhary et al., 2012).

Ficus consist of about 1000 species distributed widely from pan-tropical and subtropical origins all over the world with great diversity in South East Asia, Malaysia and tropical South America (Bercu and Popoviciu, 2014; Teleb and Salah-El-Din, 2014). Berg (1989) discovered about 105 species in the African floristic region, out of which about 60 species of Ficus are found in West Tropical Africa (Burkill, 1998) and at least 44 species are seen in Nigeria (Keay, 1989).

The habits of the genus include deciduous and evergreen trees, shrubs, herbs, climbers and creepers and also life forms including free standing tree, epiphytes, semi-epiphytes in the crevices, rheophytes and lithophytes (Chaudhary et al., 2012; Rahman and Khanom, 2013; Mawa et al., 2013). Members of Ficus are

Received: 18 Jun 2020. Received in revised form: 02 Jun 2021. Accepted: 07 Jun 2021. Published online: 23 Jun 2021.

From Volume 13, Issue 1, 2021, Notulae Scientia Biologicae journal uses article numbers in place of the traditional method of continuous pagination through the volume. The journal will continue to appear quarterly, as before, with four annual numbers. 
recognised by highly characterized inflorescence, the syconium or hypanthodium, which are hollow bags of numerous male and female flowers with fleshy receptacle, the male flowers are arranged towards an ostiole located at the free end of the receptacle, the remaining part of the cavity are occupied by female flowers. The female flowers are located close to the orifice or opening and are usually protected by sterile scales (Olorode 1984; Sharma, 1993; Clement and Wieblen, 2009).

During the last decades, plant anatomical study and its data are often used in characterization of species within a genus and in determining evolutionary relationships. Several authors have referred to plant taxonomy and application as a remarkable evolution in vascular plants studies (Stant, 1973; Metcalfe and Chalk, 1979; Forbes, 1980; Abubakar and Yunusa, 1998; Ogunkunle and Oladele, 2000; Ahmad et al., 2010; Odedeji and Adedeji, 2015; Talebi et al., 2017).

According to Sehgal and Paliwal (2008) and Ummu et al. (2014), anatomical studies of leaf venation have been proven to be useful for the identification of various species. Ummu et al. (2014) described the variation in the leaf venation of twenty-one species of Ficus in Peninsular Malaysia and observed eight leaf venation patterns. They also concluded that tracheid, cystolith cells and trichomes are anatomical characters that assist in delimiting the species. Siti-Khaulah and Noraini (2016) studied eight species of Ficus, the presence of complex veinlet, complete ultimate marginal and opened venation were observed. The report concluded that anatomical features of venation are of taxonomic significance in differentiating and identifying the studied species. Hickey (1973) indicated that the venations of leaves are associated with plant evolution and the significant role systematically in plant identification and classification. This study is to investigate the leaves venation patterns of ten species of Ficus identifying features that may be of taxonomic value in delimiting the species.

\section{Materials and Methods}

\section{Herbarium Survey}

A preliminary study of herbarium materials of the selected species of Ficus was carried out in Obafemi Awolowo University (IFE) herbarium and relevant literature were reviewed. The flora of West Tropical Africa by Hutchinson and Dalziel (1958) was also consulted.

Ten species of Ficus were collected at various locations in Southwestern Nigeria as shown in Table 1. The species of Ficus were authenticated at IFE herbarium, Obafemi Awolowo University, Ile-Ife. The Flora of West Tropical Africa by Hutchinson and Dalziel (1954-72) was also consulted. Fresh specimens collected at different collection sites were preserved in $50 \%$ ethanol.

For the venation studies, sizeable portions of the matured leaves of the species were obtained from the median parts of well expanded leaves. The leaves were decolourised by boiling in $90 \%$ ethanol (to remove chlorophyll) at $20^{\circ} \mathrm{C}$ for about 10-15 minutes, washed in 3-4 changes of water to remove all traces of alcohol. The leaves were later boiled in 5\% sodium hydroxide for 15 minutes to enhance further clearing of leaves.

The leaves were washed thoroughly to remove alkaline solution. The partially cleared leaves were further cleared in 5\% domestic bleach (parozone) for 20-30 minutes. The cleared leaves were rewashed in 3-4 changes of water, and stored in $50 \%$ ethanol as described by Olatunji (1983). These were stained in $1 \%$ aqueous solution of Safranin $\mathrm{O}$ and mounted on a clean slide in $25 \%$ glycerol for venation studies. Slides examinations were made under the light microscope. Photomicrographs of veins and areoles were made using Amscope digital camera mounted on a celesterone binocular microscope. 
Akinlabi AA and Oladipo OT (2021). Not Sci Biol 13(2):10760

Table 1. The sites of collection and the coordinates of the Ficus species studied

\begin{tabular}{|c|c|c|c|c|}
\hline $\mathrm{S} / \mathrm{N}$ & Species & $\begin{array}{l}\text { Voucher } \\
\text { Number }\end{array}$ & GPS coordinates & Description of collection sites \\
\hline 1. & $\begin{array}{c}\text { Ficus exasperata } \\
\text { Vahl }\end{array}$ & IFE- 17752 & $7^{\circ} 31^{\prime} 11^{\prime \prime} \mathrm{N} 4^{\circ} 31^{\prime} 38^{\prime \prime} \mathrm{E}$ & $\begin{array}{c}\text { Adjacent Central Science Laboratory, } \\
\text { OAU, Ile-Ife }\end{array}$ \\
\hline 2. & $\begin{array}{l}\text { Ficus recurvata } \\
\text { De Wild }\end{array}$ & IFE- 17757 & $7^{\circ} 31^{\prime} 11^{\prime \prime} \mathrm{N} 4^{\circ} 31^{\prime} 34^{\prime \prime} \mathrm{E}$ & $\begin{array}{c}\text { Biological Garden, Behind Botany car park, } \\
\text { OAU, Ile-Ife }\end{array}$ \\
\hline 3. & $\begin{array}{c}\text { Ficus mucuso } \\
\text { Welw. Ex } \\
\text { Ficalho } \\
\end{array}$ & IFE- 17755 & $7^{\circ} 31^{\prime} 13^{\prime \prime} \mathrm{N} 4^{\circ} 31^{\prime} 38^{\prime \prime} \mathrm{E}$ & $\begin{array}{c}\text { Biological Garden, Behind Botany car Park, } \\
\text { OAU, Ile-Ife }\end{array}$ \\
\hline 4. & Ficus sur Forssk & IFE- 17758 & $7^{\circ} 31^{\prime} 4^{\prime \prime} \mathrm{N} 4^{\circ} 31^{\prime} 35^{\prime \prime} \mathrm{E}$ & OAU Bus stop, Ile-Ife. \\
\hline 5. & $\begin{array}{l}\text { Ficus leprieurii } \\
\text { (Miq.) CC, Berg }\end{array}$ & 1 FE-17753 & $7^{\circ} 31^{\prime} 13^{\prime \prime} \mathrm{N} 4^{\circ} 31^{\prime} 38^{\prime \prime} \mathrm{E}$ & Reforestation Garden, OAU, Ile-Ife \\
\hline 6. & $\begin{array}{c}\text { Ficus elastica } \\
\text { Roxb. Ex } \\
\text { Hornen } \\
\end{array}$ & IFE- 17751 & $7^{\circ} 31^{\prime} 21^{\prime \prime} \mathrm{N} 4^{\circ} 31^{\prime} 47^{\prime \prime} \mathrm{E}$ & Parks and Garden, OAU, Ile-Ife. \\
\hline 7. & $\begin{array}{c}\text { Ficus benjamina } \\
\text { Vahl }\end{array}$ & IFE-17750 & $\begin{array}{c}7^{\circ} 23^{\prime} 7^{\prime \prime} \mathrm{N} 3^{\circ} 50^{\prime} 28^{\prime \prime} \mathrm{E} 7^{\circ} \\
31^{\prime} 16^{\prime \prime} \mathrm{N} 4^{\circ} 31^{\prime} 29^{\prime \prime} \mathrm{E}\end{array}$ & $\begin{array}{c}\text { 1.Moor Plantation, Apata, Ibadan } \\
\text { 2.Opposite First bank lecture theatre, OAU }\end{array}$ \\
\hline 8. & Ficus lutea Vahl & IFE- 17754 & $7^{\circ} 31^{\prime} 11^{\prime \prime} \mathrm{N} 4^{\circ} 31^{\prime} 34^{\prime \prime} \mathrm{E}$ & $\begin{array}{c}\text { Biological Garden, Behind Botany car park, } \\
\text { OAU, Ile- Ife }\end{array}$ \\
\hline 9. & Ficus polita Vahl & IFE- 17756 & $\begin{array}{l}7^{\circ} 31^{\prime} 11^{\prime \prime} \mathrm{N} 4^{\circ} 31^{\prime} 34^{\prime \prime} \mathrm{E} \\
7^{\circ} 23^{\prime} 4^{\prime \prime} \mathrm{N} 3^{\circ} 50^{\prime} 31^{\prime \prime} \mathrm{E} \\
7^{\circ} 31^{\prime} 10^{\prime \prime} \mathrm{N} 4^{\circ} 31^{\prime} 29^{\prime \prime} \mathrm{E}\end{array}$ & $\begin{array}{c}\text { 1.Biological Garden, Behind Botany car } \\
\text { park, OAU, Ile-Ife } \\
\text { 2.Moor plantation, Apata, Ibadan } \\
\text { 3.Beside OAU Library, Ile-Ife. }\end{array}$ \\
\hline 10. & $\begin{array}{l}\text { Ficus thonningii } \\
\text { Blume }\end{array}$ & IFE- 17759 & $7^{\circ} 31^{\prime} 11^{\prime \prime} \mathrm{N} 4^{\circ} 31^{\prime} 34^{\prime \prime} \mathrm{E}$ & $\begin{array}{c}\text { Biological Garden, Behind Botany car park, } \\
\text { OAU, Ile-Ife }\end{array}$ \\
\hline
\end{tabular}

${ }^{*}$ Collectors' names: Akinlabi Adebisi A.

\section{Statistical analysis}

Data collected were subjected to analysis of variance based on completely randomized design to test for significant difference among the accessions of the ten species of Ficus studied. The means were separated using Duncan's Multiple Range Test (DMRT) and photographs of some of the morphological characters of the taxa were also taken. The data were analyzed using SAS software (2003).

\section{Results}

The leaf morphology of the ten Ficus species studied showed brochidodromous venation which is a type of camptodromous venation. The secondary veins of the leaf do not terminate at the margin but were joined together forming series of prominent arches (Table 2 and Figure 1).

Ficus leprieurii (Miq) CC. Berg

Areoles well developed. The shape of the areole is polygonal. Size ranges from $92.00-180.00 \mu \mathrm{m}$ long and $76.00-116.00 \mu \mathrm{m}$ wide. Veinlets ending is simple and are mostly branched, ranges from 0 - 6 in number. 


\section{Ficus thonningii Blume}

Areoles are well developed and their shape ranges from rectangular to pentagonal, size ranges from 88.00 $\pm 3.20 \mu \mathrm{m}$ wide and $116.80 \pm 5.61 \mu \mathrm{m}$ long. Veinlets ending are mostly linear and occasionally branched or forked, 0 - 3 per areole.

\section{Ficus mucuso Welw. Ex Ficalho}

Areole are well developed, shape varies from triangular to rectangular, $84.00-160.00 \mu \mathrm{m}$ long and 60.00 - $120.00 \mu \mathrm{m}$ wide. Silicified bodies with cellulose skeleton (Cystolith cells) and trichomes were present. It has no veinlets ending.

\section{Ficus lutea Vahl}

Areoles are developed with shape ranging from triangular to polygonal, about $88.00-148.00 \mu \mathrm{m}$ long and $68.00-112.00 \mu \mathrm{m}$ wide. Veinlets ending are simple, linear and occasionally branched and $0-3$ veinlets per areole.

\section{Ficus polita Vahl}

Areoles are well developed, rectangular to triangular in shape. Shape ranges from $112.00-180.00 \mu \mathrm{m}$ long to 64.00 - $128.00 \mu \mathrm{m}$ wide. Veinlets ending are simple, linear and branched, 0 - 1 per areole.

\section{Ficus sur Forssk}

Areoles are well developed with shape largely triangular to polygonal. Areole size ranges from 56.00 $120.00 \mu \mathrm{m}$ long to $52.00-96.00 \mu \mathrm{m}$ wide. Veinlets ending are simple and forked, 0 - 2 per areole.

\section{Ficus benjamina Vahl}

Areoles are well developed, shape vary from triangular, rectangular and quadrangular, about 60.00 $100.00 \mu \mathrm{m}$ long to $40.00-60.00 \mu \mathrm{m}$ wide. Veinlets ending are simple, linear and mostly bifurcated. Veinlet ending ranges from 0 - 3 per areole.

\section{Ficus exasperata Vahl}

Areoles are well developed, largely rectangular to triangular. Areole length varies from $92.00-160.00$ $\mu \mathrm{m}$ and areole width ranges from $60.00-116.00 \mu \mathrm{m}$. Veinlets ending are linear to branched and ranges from 0 -3 per areole.

Ficus recurvata De Wild

Areoles are well developed; shape vary from rectangular to polygonal and size from $44.00-100.00 \mu \mathrm{m}$ long to $40.00-84.00 \mu \mathrm{m}$ wide. Veinlets ending are simple, linear and branched and with about $0-3$ per areole.

\section{Ficus elastica Roxb. Ex Hornem}

Areoles are well developed with shape ranging from triangular to pentagonal to polygonal. Areole size varies $84.00-192.00 \mu \mathrm{m}$ long and $64.00-180.00 \mu \mathrm{m}$ wide. The veinlets ending are singly divided and ranges between 0 - 3 per areole. 

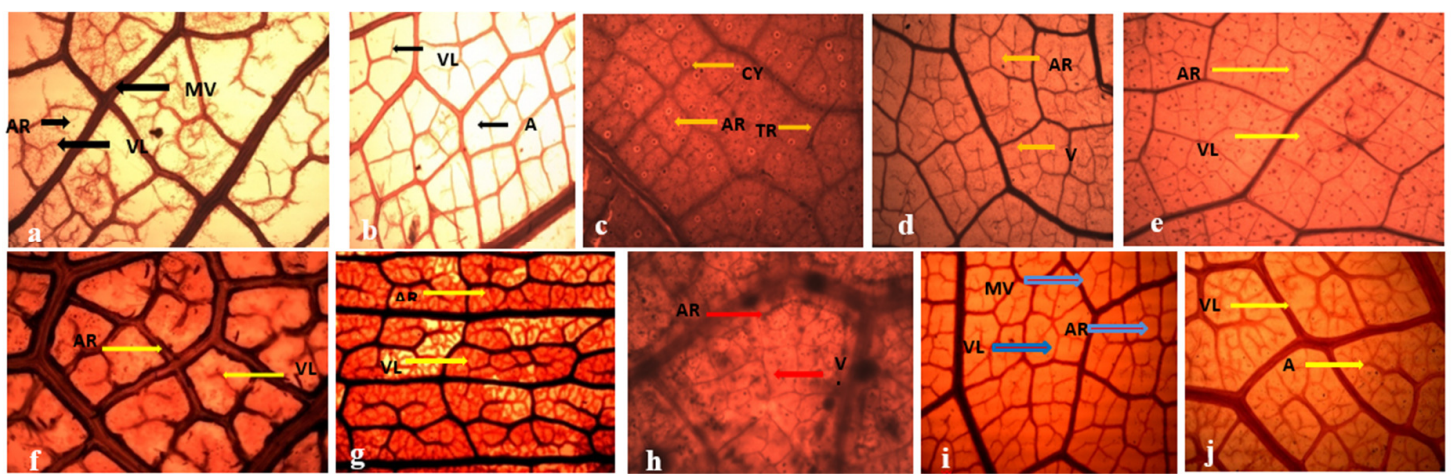

Figure 1. The venation patterns of the species studied

a) F. leprieurii; b) F. thonningii; c) F. mucuso; d) F. lutea e) F. polita; f) F. sur, g) F. benjamina; h) F. exasparata; i) F. recurvata; j) F. elastica

Legend: $\mathrm{MV}=$ Main Vein, $\mathrm{VL}=$ Veinlet, $\mathrm{AR}=$ Areole, $\mathrm{CY}=$ Cystolith, $\mathrm{TR}=$ Trichome

Table 2. Quantitative parameter of the venation pattern of ten Ficus species studied

\begin{tabular}{|c|c|c|c|}
\hline Plant species & Areole width $(\mu \mathrm{m})$ & Areole length $(\mu \mathrm{m})$ & Number of veinlets ending \\
\hline Ficus lutea & $92.27 \pm 7.54^{\mathrm{b}}$ & $120.00 \pm 4.84^{\mathrm{a}}$ & $0-3$ \\
\hline F. thonningii & $88.00 \pm 3.22^{\mathrm{b}}$ & $116.80 \pm 5.61^{\mathrm{a}}$ & $0-3$ \\
\hline F. exasperata & $87.47 \pm 3.84^{\mathrm{b}}$ & $120.00 \pm 3.84^{\mathrm{a}}$ & $0-3$ \\
\hline F. mucuso & $84.27 \pm 4.05^{\mathrm{b}}$ & $116.27 \pm 5.16^{\mathrm{a}}$ & $0-3$ \\
\hline F.recurvata & $54.40 \pm 4.15^{\mathrm{c}}$ & $70.40 \pm 4.38^{\mathrm{b}}$ & $0-6$ \\
\hline F. leprieurii & $107.00 \pm 4.70^{\mathrm{a}}$ & $132.80 \pm 4.83^{\mathrm{a}}$ & $0-1$ \\
\hline F. polita & $96.53 \pm 3.84^{\mathrm{a}}$ & $130.67 \pm 3.88^{\mathrm{ab}}$ & $0-2$ \\
\hline F. sur & $68.53 \pm 3.29^{\mathrm{c}}$ & $82.67 \pm 5.20^{\mathrm{b}}$ & $0-3$ \\
\hline F. elastica & $103.2 \pm 9.54^{\mathrm{a}}$ & $131.47 \pm 8.76^{\mathrm{a}}$ & $0-3$ \\
\hline F. benjamina & $55.73 \pm 3.47^{\mathrm{b}}$ & $80.8 \pm 2.80^{\mathrm{c}}$ & \\
\hline
\end{tabular}

${ }^{*}$ Means with the same letter along columns are not significantly different at $\mathrm{P} \leq 0.05$

\section{Discussion}

Variations in patterns of leaf venation are not just useful in identifying taxon, but can also be used in differentiating between species of a genus. Rich diversity of venation patterns was observed in monocotyledons by Inamdar et al. (1983) and dicotyledonous plants by Hickey (1973). Areole shape in the Ficus species studied ranges from triangular, rectangular, and pentagonal to polygonal. Ogundipe and Wujek (2004) identified the significance of veinlet termination endings in the family Bignoniaceae. Characters of venation such as welldeveloped areole are classificatory for the species of Ficus studied. 0 - 3 veinlets ending were classificatory for $F$. exasperata, F. benjamina, F. thonningii and F. lutea, F. elastica and F. recurvata. Ficus sur has 0 - 2 veinlets ending, Ficus polita had $0-1$ veinlets ending and Ficus mucuso had no veinlets ending. The $0-6$ veinlets ending in Ficus leprieurii is diagnostic of the species.

Cystolith cells are silicified bodies with cellulose skeleton and trichomes were present only in F. mucuso and are diagnostic of the species. Siti-Khaulah and Noraini (2016) also reported the presence of cystolith cells in F. pubigera and opened areolar venation in most Ficus species studied but concluded that leaf venation has taxonomic significance in differentiation and identification of species. The cystolith cells are made of calcium carbonate located in lithocysts and occur in either papillate or hair-like form, usually found in the epidermis of leaves (Mauseth 1988; Ummu et al., 2014). Also, as far back as 1950, Metcalfe and Chalk have reported the presence true cystoliths in some genera of Moraceae, such as Broussonetia, Chlorophora, Conocephalus, Ficus 
and Morus. Consequently, the presence of cystoliths in F. mucuso is a common characteristic of the genus Ficus which is unique to certain species.

Also, the importance of trichomes have been emphasized in literatures (Ramayya and Rao, 1976; Rao and Ramayya, 1977; Adedeji et al., 2007). Among the ten Ficus species studied, trichomes were only present in F. mucuso. Various type of trichomes, such as straight and long, short and peltate have been observed on leaves in Ficus taxa according to Klimko and Truchan (2006). Ummu et al. (2014) also reported, simple and unicellular trichomes in the leaf venation of some species, such as in $F$. aurantiacea var. aurantiacea, $F$. aurata, F. benghalensis, F. fulva, F. hispida, F. lepicarpa, F. sagittata and F. superba.

The venation pattern revealed intraspecific and interspecific differences among the Ficus species studied based on quantitative attributes i.e the areole width and areole length. However, characters like long areole length is classificatory for species such as F. polita, F. elastica, F. lutea, F. exasperata, F. mucuso, F. thonningii and $F$. leprieurii having significantly longer areole length. This agrees with current sectional grouping of the species in Galoglychia excluding F. exasperata and F. mucuso in section Sycidium and Sycomorous respectively. F. sur, F. benjamina and F. recurvata have short areole length. The significantly wide areole in $F$. leprieurii and F. elastica with $(107.00 \pm 4.70 \mu \mathrm{m}$ and $103.2 \pm 9.54 \mu \mathrm{m})$ respectively is also classificatory of the species and this distinguishes them from other Ficus species and they are both in section galoglychia and it agrees with the sectional classification of Berg (1989).

\section{Conclusions}

The venation patterns in all the ten Ficus species studied are unique with respect to the areole shape, width and length as well as the veinlets ending. The study emphasized the taxonomic importance of leaf venation and its pattern usefulness in delimiting the species of the taxon. The study therefore concluded that the information will be useful in further taxonomic study of the genus Ficus.

\section{Authors' Contributions}

Both authors read and approved the final manuscript.

\section{Acknowledgements}

The authors are grateful to Mr. MS Akinropo, Dr. AJ Akinloye and Mr. A Omole of the Department of Botany, O.A.U Ile-Ife, for the kind gestures provided during the laboratory work.

\section{Conflict of Interests}

The authors declare that there are no conflicts of interest related to this article. 


\section{References}

Abubakar BY, Yunusa AI (1998) Epidermal structure and stomata ontology as an aid to taxonomic identification of some species of Acasia (Legominose-Mimosoideae). Nigerian Journal of Botany 11:117-123.

Adedeji, O, Ajuwon OY and Babawale OO (2007). Foliar epidermal studies, organographic distribution and taxonomic importance of trichomes in the family Solanaceae. International Journal of Botany 3(3):276-282. https://doi.org/10.3923/ijb.2007.276.282

Ahmad K, Khan M, Ahmad M, Shaheen N, Abdul Nazir A (2010). Taxonomic diversity in epidermal cells of some subtropical plant species. International Journal of Agriculture and Biology 12:115-118.

Bercu R, Popoviciu DR (2014). Anatomical study of Ficus carica Linn leaf. Annals of Romanian Society of Cell Biology 19(1):33-36. https://doi.org/10.ANN/RSCB-2014-0002:RSCB

Berg CC (1989). Systematics and phylogeny of the urticales in evolution. In: Crane PR, Blackmore S (Eds). Systematics and Fossil History of the Hamamelidae. Clarendon Press, Oxford pp 193-220.

Burkill HM (1998). The useful plants of West Tropical Africa 2. Volume 4. Families M.R Kew: Royal Botanical Garden, Kew.

Chaudhary LB, Sudhakar JV, Kumar A, Bajpai O, Tiwari R, Murthy GVS (2012). Synopsis of the genus Ficus Linn. (Moraceae) in India. Taiwania 57:193-216.

Clement WL, Weiblen GD (2009). Morphological evolution in the mulberry family (Moraceae). Systematic Botany 34(3):530-552. https://doi.org/10.1600/036364409789271155

Dede RA (1962). Foliar venation patterns in the Rutaceae. American Journal of Botany 49(5):490-497. https://doi.org/10.1002/j.1537-2197.1962.tb14970.x

Forbes PL (1980). A revision of Fuirena Rottb. (Cyperaceae) in Southern Africa. Ph.D. dissertation, Univ. Witwatersrand, Johannesburg.

Frodin DG (2004). History and concepts of big plant genera. Taxon International Journal of Plant Taxonomy 53:753776. https://doi.org/10.2307/4135449

Hickey LJ (1973). Classification of the architecture of dicotyledonous leaves. American Journal of Botany 60:17-33. https://doi.org/10.2307/2441319

Hutchinson J, Dalziel MD (1954 - 1972). Floral of West Tropical Africa. Volumes 3, Crown Agents, London.

Inamdar JA, Shenoy KN, Rao NV (1983). Leaf architecture of some monocotyledons with reticulate venation. Annals of Botany 52(5):725-735.

Keay RWJ (1989). Trees of Nigeria. Oxford science Publications. Clarendon Press, Oxford, pp 476.

Klimko M, Truchan M (2006). Morphological variability of the leaf epidermis in selected taxa of the genus Ficus. L. (Moraceaea) and its taxonomic implications. Acta Societatis Botanicorum Poloniae 75(4):309-324. https://doi.org/10.5586/asbp.2006.038

Mauseth JD (1988). Plant anatomy. California: The Benjamin Cummings Publication Company Inc., pp 32-34.

Mawa S, Husain K, Jantan I (2013). Ficus carica L. (Moraceae): phytochemistry, traditional uses and biological activities. Evidence-Based Complementary and Alternative Medicine 1:8 https://doi.org/10.1155/2013/974256

Metcalfe CR, Chalk L (1950). Anatomy of the dicotyledons. Volume 2. Clarendon Press, Oxford, UK pp 1259-1271.

Olorode O (1984). Taxonomy of West African flowering plant. Longman Publishing Company, New York, pp 25-32.

Ogundipe OT, Wujek DE (2004). Foliar anatomy on twelve genera of Bignoniaceae (Lamiales). Acta Botanica Hungarica 46(3-4):337-361. https://doi.org/10.1556/abot.46.2004.3-4.7

Odedeji ET, Adedeji O (2015). Comparative Foliar epidermal studies of twelve species in the family Cyperaceae. Journal of Advanced Laboratory Research in Biology 6(4):111-123.

Ogunkunle ATJ, Oladele FA (2000) Diagnostic value of trichomes in some Nigerian species of Ocimum. Hyptis Jazq. and Tinnea Kostschy and Peys (Lamiaceae). Journal of Applied Sciences 3:1163-1180.

Olatunji OA (1983). Practical manual for plant anatomy. A Laboratory Practical Manual, Department of Botany, Obafemi Awolowo University, Ile - Ife, Nigeria (Manuscript).

Rahman AHM, Khanom A (2013). Taxonomic and ethno-medicinal study of species from Moraceae (Mulberry) family in Bangladesh flora. Research in Plant Sciences 1(3):53-57. https://doi.org/10.12691/plant-1-3-1

Raju SV, Rao PN (2008). Variation in the structure and development of foliar stomata in the Euphorbiaceae. Botanical Journal of the Linnean Society 75:69-97. https://doi.org/10.1111/j.1095-8339.1977.tb01479.x

Ramayya N, Rao SRS (1976). Morphology, phylesis and biology of the peltate scale, stellate and tufted hairs in some Malvaceae. Journal of the Indian Botanical Society 55:75-79. 
Rao SRS, Ramayya N (1977). Structure distribution and taxonomic importance of trichomes in the Indian species of Malvastrum. Phytomorphology 27:40-44.

Rao PN, Raju VS (1985) Foliar trichomes in the family Euphorbiaceae. In: Trends in Plant Research. Prof. YS Murthy Commemorative Volume. Bishen Singh Mahendra Pal Singh, Dehra Dun, India, pp 128-136.

Stace CA (1984). The taxonomic importance of the leaf surface. In: Heywood VH and Moore DM (Eds). Current Concepts in Plant Taxonomy. Academic Press, London.

Stant MY (1973). Scanning electron microscopy of silica bodies and other epidermal features in Gibasis (Tradescantia) leaf. Botanical Journal of the Linnean Society 66:233-243. https://doi.org/10.1111/j.10958339.1973.tb02172.x

Sehgal L, Paliwal GS (2008). Studies on the leaf anatomy of Euphorbia: II Venation patterns. Botanical Journal of Linnean Society 68(3):173-208. https://doi.org/10.1111/j.1095-8339.1974.tb01612.x

Scott T (1996). Concise encyclopedia biology. Walter de Gruyter, New York pp 77.

Sharma OP (1993). Plant taxonomy. Tata McGraw - Hill publishing company Limited. New Delhi pp 482.

Siti-Khaulah AR, Noraini T (2016). Leaf venations in some Ficus L. (Moraceae) species. In: 2016 UKM FST Postgraduate Colloquium: Proceedings of the University Kebangsaan Malaysia, Faculty of Science and Technology 2016 Postgraduate Colloquium pp 1784. https://doi.org/10.1063/1.4966885

SAS Institute (2003). SAS Procedure guides, Version 9.1 Cary, SAS Institute.

Talebi MS, Noori M, Naniz AH (2017). A study of epidermal leaf anatomy of 18 Euphorbia taxa from Kerman Province, Iran. Biologija 63(2):126-133. https://doi.org/10.6001/biologija.v63i2.3524

Teleb SS, Salah-El-din RM (2014). Pollen morphology of some species of genus Ficus L. (Moraceae) from Egypt. Egypt Journal of Botany 54(1):87-102. https://doi.org/10.21608/ejbo.2014.481

Ummu HB, Noraini T, Abdul LM, Affina EAA, Amirul AJ (2014). Studies on leaf venation in selected taxa of the genus Ficus L. (Moraceae) in Peninsular Malaysia. Tropical Life Sciences Research 25(2):111-125.
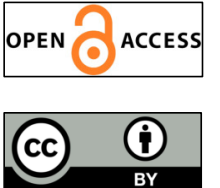

The journal offers free, immediate, and unrestricted access to peer-reviewed research and scholarly work. Users are allowed to read, download, copy, distribute, print, search, or link to the full texts of the articles, or use them for any other lawful purpose, without asking prior permission from the publisher or the author.

License - Articles published in Notulae Scientia Biologicae are Open-Access, distributed under the terms and conditions of the Creative Commons Attribution (CC BY 4.0) License.

(c) Articles by the authors; SHST, Cluj-Napoca, Romania. The journal allows the author(s) to hold the copyright/to retain publishing rights without restriction. 